\title{
Effect of fasting and fasting-refeeding on the structure, metabolism and transport functions of renal cortical proximal tubules from different kidney regions
}

\author{
Samina Salim, Zeba Farooqui, Mohammad Asghar, Syed Jalal Khundmiri, Farah Khan and Ahad Noor Khan Yusufi*
}

Department of Biochemistry, Aligarh Muslim University, Aligarh, Uttar Pradesh, India

\begin{abstract}
The effect of fasting and fasting-re-feeding was studied on certain serum parameters; enzymes of brush border membrane and carbohydrate metabolism; transport of $\mathrm{Pi}$ in different anatomical parts of rat kidney. Fasting decreased the activities of lactate dehydrogenase (LDH), malate dehydrogenase (MDH) but increased the activities of glucose-6-phosphatase (G6Pase) and fructose 1, 6-bisphosphatase (FBPase); glucose-6-phosphate dehydrogenase (G6PDH) and malic enzyme (ME). Activities of brush border membrane (BBM) and the transport of Pi in BBM vesicles prepared from superficial and juxta-medullary cortex were also decreased. The feeding of a normal diet to fasted rats reversed the effect of fasting on various parameters. The activities of BBM enzymes and Pi transport elevated to above fasting levels close to control values. Kinetic parameters determined for BBM enzymes and Pi transport affected by fasting and/or re-feeding by alteration in the $\mathrm{V}_{\text {max }}$ and $\mathrm{K}_{\mathrm{m}}$ values. The enzymes of glucose degradation decreased but those of its production increased by fasting were also returned back towards control values by re-feeding. Serum Pi, phospholipids and cholesterol affected by fasting were also normalized by re-feeding. The results show that fasting caused significant decrease in metabolic enzymes involved in energy generation caused decrease in transport functions of the kidney but re-feeding could ameliorate the effect of fasting. In conclusion, the results show that the kidney can adapt too much greater extent under acute situations
\end{abstract}

\begin{abstract}
Abbreviations: AlkPase: Alkaline phosphatase; BBM: Brush border membrane; BUN: Blood urea nitrogen; BBMV: Brush border membrane vesicle; FBPase: Fructose 1,6-bisphosphatase; G6PDH: Glucose-6-phosphate dehydrogenase; GGTase: $\gamma$-glutamyl transferase; HK: Hexokinase; HMP: Hexose monophosphate; JMC: Juxtamedullary cortex; LDH: Lactate dehydrogenase; MDH: Malate dehydrogenase; ME: Malic enzyme; NADPH: Nicotinamide adenine dinucleotide phosphate reduced; NADP: Nicotinamide adenine dinucleotide phosphate; SC: Superficial cortex; WC: Whole cortex
\end{abstract}

\section{Introduction}

The kidney plays an extremely important role in the maintenance of body fluid volume, its composition and $\mathrm{pH}$ with in physiological range by virtue of its reabsorption properties [1]. It is vulnerable to damaging effects by changes in physiologic and pathophysiologic conditions such as fasting, under nutrition, and from variety of substances with nephrotoxic potential [2-4].

People have been fasting for health or religious reasons since ancient times. Every religion has sanctioned some form of fasting, though, with different mode and duration. However, nutritional stress in different forms can produce variable effects on human health. For example, fasting (starvation) is known to produce extensive changes in the structure and functions of intestine, liver and kidney $[2,5,6]$. However, short-term fasting followed by re-feeding, restricted calorific intake, intermittent fasting and/or Ramadan fasting (Islamic fasting) in which Muslims fast dawn to dusk and allowed to eat after sunset to dawn for about a month have been shown to have beneficial effects in humans and experimental animals [7-9].

Recently, we have reported that 1,3 , or 5 days fasting caused alterations in the activity of certain enzymes of glycolysis, TCA-cycle and HMP-shunt pathway but enzymes of gluconeogenesis were increased by fasting in rat intestine and kidney $[2,10]$. BBM biomarker enzymes and transport of Pi was also decreased by 1,3 , and $5 \mathrm{~d}$ fasting in superficial and juxta-medullary cortex of rat kidney [10]. Now we have determined the effect of fasting and fasting-re-feeding on the enzymes of carbohydrate metabolism, BBM in the homogenates and/ or BBMVs prepared from whole (BBMV-WC), superficial (BBMV-SC) and juxta- medullary cortex (BBMV-JMC) of rat kidney. The transport of Pi was also simultaneously determined under same experimental conditions in freshly prepared BBM vesicles. The results show that fasting caused significant decrease in metabolic enzymes involved in energy generation that caused decrease in transport functions of the kidney but re-feeding prevented the effect of fasting and caused increase in energy metabolism, BBM integrity and transport of Pi. In conclusion, the results show that the kidney has much greater capacity to adapt and try to keep positive balance of various ions and nutrients under acute situations.

\section{Material and methods}

Wistar rats were purchased from All India Institute of Medical Sciences (New Delhi, India). ${ }^{32} \mathrm{Pi}$ was purchased from Bhabha Atomic

Correspondence to: Yusufi ANK, Department of Biochemistry, Faculty of Life Sciences, Aligarh Muslim University, Aligarh-202002, Uttar Pradesh, India, Tel: 919760429382; E-mail: yusufi@lycos.com, ayusufi@gmail.com

Key words: fasting and re-feeding; carbohydrate metabolism; brush border membrane enzymes; pi transport; kidney

Received: October 02, 2017; Accepted: October 23, 2017; Published: October 26, 2017 

regions

Research center (Mumbai, India). All other chemicals used were of analytical grade and were purchased from Sigma Chemical Co. (St Louis, MO, USA) unless otherwise stated.

\section{Experimental design}

Adult male Wistar rats weighing 100-125 g, fed with a standard rat diet (Amrut Laboratories, Pune, India) and water ad libitum, were conditioned for one week before the start of the experiment. All animals were kept under conditions that prevented them from experiencing unnecessary pain according to the guide lines of Institution Ethical Committee. Initially, the rats were fasted for 2 days and then divided into two groups. While one group (fasted) of rats continue to fast for another $2 \mathrm{~d}$, the other group (fasted-re-fed) was fed with standard rat diet for $2 \mathrm{~d}$. During fasting and fasting re-feeding, rats were given ad libitum $1 \%$ glucose-water to reduce the mortality due to fasting (up to 4 days). The unfasted rats received standard diet and $1 \%$ glucose water was used as the control. The experiment was designed in such a way that all of the animals (fasted, fasted-re-fed and control) were sacrificed on the same day under light ether anaesthesia. The weight of the animals were recorded at the start and after completion of the experiment. Blood and urine samples were collected and the kidneys were harvested and utilized for further analyses.

\section{Preparation of homogenates}

After the completion of the experiment, the kidneys were removed, encapsulated and kept in ice-cold buffered saline $(154 \mathrm{mM} \mathrm{NaCl}, 5$ $\mathrm{mM}$ Tris-HEPES, $\mathrm{pH}$ 7.5). The whole cortex and superficial and juxtamedullary cortex were carefully separated as described earlier [11]. A $15 \%(\mathrm{w} / \mathrm{v})$ homogenate was prepared in $0.1 \mathrm{M}$ Tris- $\mathrm{HCl}$ buffer $\mathrm{pH} 7.5$ using Potter-Elvehejem homogenizer (Remi motors, Mumbai, India) with five complete strokes. The homogenate was centrifuged at $3000 \mathrm{~g}$ at $4^{\circ} \mathrm{C}$ for $15 \mathrm{~min}$ to remove cell debris and the supernatant was saved in aliquots and stored at $-20^{\circ} \mathrm{C}$ for assaying various enzymes.

\section{Preparation of brush border membrane vesicles (BBMV) from various tissue zones of the kidney}

BBMV were prepared from the homogenates of whole cortex (WC), superficial cortex (SC) and juxta-medullary cortex (JMC) using the $\mathrm{MgCl}_{2}$ precipitation method as previously described [3]. Briefly, freshly minced tissues were homogenized in $50 \mathrm{mM}$ mannitol and 5 $\mathrm{mM}$ Tris-HEPES buffer $\mathrm{pH} 7.0(20 \mathrm{ml} / \mathrm{g})$, in a glass teflon homogenizer with 4 complete strokes. The homogenate was then subjected to high speed homogenization in an Ultra Turex homogenizer (Type T-25, Janke \& Kunkel GMBH \& Co. KG. Staufen) for three strokes of 15 s each with an interval of $15 \mathrm{~s} . \mathrm{MgCl}_{2}$ was added to the homogenate to a final concentration of $10 \mathrm{mM}$ and the mixture stirred for $20 \mathrm{~min}$ on ice. The homogenate was centrifuged at $2000 \mathrm{~g}$ for $10 \mathrm{~min}$ in a Beckman centrifuge (J2 MI, Beckman instruments Inc, Palo Alto, C.A. USA) using JA-17 rotor and the supernatant was then recentrifuged at $35,000 \mathrm{~g}$ for $30 \mathrm{~min}$. The pellet was resuspended in $300 \mathrm{mM}$ mannitol and $5 \mathrm{mM}$ Tris-HEPES, $\mathrm{pH}$ 7.4, with four passes by a loose fitting Dounce homogenizer (Wheaton IL, USA) and centrifuged at $35,000 \mathrm{~g}$ for $20 \mathrm{~min}$ in a $15 \mathrm{ml}$ corex tube. The outer white fluffy pellet of BBMV was resuspended in small volume of buffered $300 \mathrm{mM}$ mannitol. Aliquots of homogenates and BBMV were saved and stored at $-20^{\circ} \mathrm{C}$ for BBM enzyme analyses. Each sample of BBMV was prepared by pooling tissues from 3-4 rats.

\section{Serum chemistries}

Serum samples were deproteinated with $3 \%$ trichloroacetic acid in a ratio $1: 3$, left for $10 \mathrm{~min}$ and then centrifuged at $2000 \mathrm{~g}$ for 10 min. The protein free supernatant was used to determine inorganic phosphate and creatinine. The precipitate was used to quantitate total phospholipids (PLs). Blood Urea Nitrogen (BUN) and cholesterol (Ch) levels were determined directly in serum samples. Glucose was estimated by o-toluidene method using kit from Span diagnostics (Mumbai, India). These parameters were determined by standard procedures as mentioned in a previous study [9].

\section{Enzyme assays}

The activities of BBM biomarkers enzymes, alkaline phosphatase (AlkPase), $\gamma$-glutamyl transferase (GGTase) in the homogenates and BBM preparations were determined as described earlier [3]. The enzymes of carbohydrate metabolism, e.g., Lactate Dehydrogenase $(\mathrm{LDH})$, malate dehydrogenase (MDH), glucose-6-phosphate (G6PDH) dehydrogenase and NADP-Malic Enzyme (ME), involved in oxidation of NADH or reduction of NADP were determined by measuring the extinction changes at $340 \mathrm{~nm}$ in a spectrophotometer (Cintra 5; GBC Scientific Equipment, Pty., Victoria Australia) as described elsewhere $[9,12]$. The other enzymes, glucose-6-phosphatase (G6Pase), fructose1,6-bisphospatase (FBPase) and hexokinase (HK) were determined as described in our previous studies [9]. Protein concentration was determined by the modified method of Lowry, et al. [12].

\section{Transport of ${ }^{32} \mathrm{Pi}$}

Measurement of ${ }^{32} \mathrm{Pi}$ transport was determined in freshly prepared BBMV-WC, BBMV-SC and BBMV-JMC at $25^{\circ} \mathrm{C}$ by rapid filtration technique as described by Yusufi, et al. [11] either in the presence or absence of Na-gradient. Uptake was initiated by addition of $30 \mu \mathrm{l}$ of incubation medium containing $100 \mathrm{mmol} / \mathrm{l}$ mannitol, $\mathrm{NaCl} / \mathrm{KCl} 100$ mmol/l, $5 \mathrm{mmol} / \mathrm{l}$ Tris-HEPES, pH 7.5, $0.1 \mathrm{mmol} / \mathrm{l} \mathrm{K}_{2} \mathrm{H}_{32} \mathrm{PO}_{4}$ to $15 \mu \mathrm{l}$ BBM suspension (50-100 $\mu$ g protein) and incubated for the desired time intervals (see Results). The uptake was stopped by the addition of 3 $\mathrm{ml}$ ice-cold stop solution (containing $135 \mathrm{mmol} / \mathrm{l} \mathrm{NaCl}, 5 \mathrm{mmol} / \mathrm{l}$ TrisHEPES and $10 \mathrm{mM}$ sodium arsenate, $\mathrm{pH}$ 7.5) and filtered immediately through $0.45 \mu \mathrm{m}$ DAWP Millipore (USA) filter and washed three times with the stop solution using a Cornwall-type syringe (Wheaton, IL). Correction for non-specific binding to filters was made by subtracting from all data the value of corresponding blank obtained by filtration of the incubation buffer without vesicles. The radioactivity of dried filters was measured by a liquid scintillation counter (Reckbeta, LKB, Wallac, Sweden) with $10 \mathrm{ml}$ scintillation fluid (Cocktail T, SRL, India).

\section{Statistical analyses}

All data are expressed as Mean \pm SEM for at least 4-5 different preparations. Statistical evaluation was conducted by one-way ANOVA and by unpaired student's t test using SPSS 7.5 software. A probability level of $\mathrm{p}<0.05$ was selected as indicating statistical significance. All the changes were compared with control values for better understanding and clarity.

\section{Results}

In the present study, the effect of fasting and fasting-re-feeding was observed on various serum and urine parameters and on the enzymes of carbohydrate metabolism, biomarker enzymes of BBM in the homogenates and BBM preparations from whole, superficial and juxtamedullary cortex. BBM transport of Pi was also observed in fasted and re-fed rats in BBMV-WC, BBMV-SC and BBMV-JMC.

\section{Body and kidney weights}

In general, the rats remained clinically well during the experimental conditions. The control rats gained weight during $4 \mathrm{~d}$ experimental period. As shown in Table 1, fasting for $4 \mathrm{~d}$ resulted in the loss of 

regions

bodyweight. However, the weight of fasted-refed rats was slightly higher than their initial weights but was lower than those of control rats. The weights of kidney and cortical tissue were slightly lowered by fasting and recovered by re-feeding (Table 1).

\section{Serum and urine parameters}

There was no effect of fasting and fasting-re-feeding on serum and urinary creatinine levels indicating that normal functions of the kidney were not affected (Table 2). Serum and urine Pi were significantly declined whereas serum PL $(+39.37 \%)$ and Ch $(+29.2 \%)$ increased by fasting as reported in previously [10]. However, re-feeding to fasted rats reversed the effect of fasting and these parameters reverted towards control values. Serum Ch/PL ratio slightly decreased in fasted rats, while it was significantly increased $(+43 \%)$ in fasted-refed rats and even surpassed the control values (Table 2).

\section{Effect of fasting and fasting-re-feeding on the activities of BBM- marker enzymes in BBMV-WC, BBMV-SC and BBMV-JMC}

As observed earlier [10] the activities of AlkPase and GGTase in BBMV-WC were significantly decreased by fasting (Table 3 ). The effect of fasting was much greater on GGTase $(-43.3 \%)$ activity compared to AlkPase (-13.92\%). Refeeding to fasted rats resulted in the increased activities of these enzymes in BBMV. When the effect of fasting and re-feeding was further analyzed in BBMV-SC and BBMV-JMC, the activities of both AlkPase and GGTase were greatly decreased by fasting in BBMV-JMC than in BBMV-SC. However, the activities of both the enzymes recovered towards the control values by re-feeding to fasted rats (Table 3).

Effect of fasting and fasting-re-feeding on the activities of certain enzymes of carbohydrate metabolism in superficial and juxtamedullary cortex

The effect of fasting and fasting-re-feeding was determined on the activities of enzymes belonging to various carbohydrate metabolic pathways in different regions of kidney tissues. $4 \mathrm{~d}$ fasting resulted in marked decrease of $\mathrm{LDH}$ and $\mathrm{MDH}$ activities. The decrease was evidently greater in JMC-H $(-42.6 \%,-49.9 \%)$ than SC-H $(-30.5 \%$, $-18 \%$ ) (Table 4). Refeeding to fasted rats resulted in significant increase in the activity of the above enzymes above fasting levels nearer to control values. However, the recovery was greater in SC-H than JMC-H. In contrast to $\mathrm{LDH}$ and MDH, the activities of FBPase, G6Pase (gluconeogenic enzymes), G6PDH (HMP-shunt pathway) and ME (biosynthetic importance) were significantly increased in $4 \mathrm{~d}$ fasted rats (Table 4). The increase of FBPase and G6Pase was markedly greater in SC-H, while G6PDH and ME were markedly increased in JMC-H than SC-H. Refeeding to fasted rats resulted in the complete normalization

Table 1. Effect of fasting and refeeding on body weight, kidney weight and cortex weight of rats [Results are expressed as Mean \pm SEM for $n=6$ rats in each group; Starting mean body weight was $106.25 \pm 0.54$ for $n=24$ rats; ${ }^{\mathrm{c}}$ Significantly different from the weight as in (a), $\mathrm{p}<0.05$ or higher degree of significance by group t-test; ${ }^{\mathrm{d}}$ Significantly different from the control, $\mathrm{p}<0.05$ or higher degree of significance by group t-test]

\begin{tabular}{|c|c|c|c|c|c|}
\hline Groups & $\begin{array}{l}\text { Body weight } \\
\text { (gms) }\end{array}$ & $\begin{array}{c}\% \text { Change body weight } \\
\text { (gms) }\end{array}$ & $\begin{array}{c}\text { Kidney weight/rat } \\
\text { (gms) }\end{array}$ & $\begin{array}{c}\text { Cortex weight } / \text { rat } \\
\text { (gms) }\end{array}$ & $\begin{array}{c}\text { Kidney weight/body weight } \\
\text { ratio }\end{array}$ \\
\hline Control & $190.8 \pm 2.07$ & +18.0 & 1.38 & $2.26 \pm 0.05$ & 0.007 \\
\hline $4 \mathrm{~d}$ fasting & $140.5 \pm 3.70^{c}$ & +13.3 & $1.25 \pm 0.01^{\mathrm{d}}$ & $1.04 \pm 0.03^{\mathrm{d}}$ & 0.008 \\
\hline $\begin{array}{l}2 \mathrm{~d} \text { fasting } \\
2 \mathrm{~d} \text { refeeding }\end{array}$ & $172.5 \pm 2.69^{c}$ & +8.0 & $1.37 \pm 0.104$ & $1.14 \pm 0.009$ & 0.009 \\
\hline
\end{tabular}

Table 2. Effect of fasting and refeeding on a) serum and b) urine parameters [Results are expressed as Mean \pm SEM for $n=10$ rats in each group; "Significantly different from control, $\mathrm{p}<0.05$ by group t-test; Values in parentheses represent percent change from control values; $\mathrm{C} / \mathrm{P}$ ratio= Cholesterol versus phospholipid ratio]

\begin{tabular}{|c|c|c|c|c|c|c|c|}
\hline \multicolumn{6}{|c|}{ a) Serum } & \multicolumn{2}{|c|}{ b) Urine } \\
\hline Group/Parameters & $\begin{array}{c}\text { Creatinine } \\
(\mu \mathrm{moles} / \mathrm{ml})\end{array}$ & $\begin{array}{l}\text { Phosphate } \\
(\mu \mathrm{g} / \mathrm{ml})\end{array}$ & $\begin{array}{l}\text { Phospholipids } \\
(\mu \mathrm{g} / \mathrm{ml})\end{array}$ & $\begin{array}{c}\text { Cholesterol } \\
(\mathrm{mg} / \mathrm{ml})\end{array}$ & $\mathrm{C} / \mathrm{P}$ ratio & $\begin{array}{l}\text { Creatinine } \\
(\mu \text { moles } / \mathrm{ml})\end{array}$ & $\begin{array}{c}\text { Phosphate } \\
(\mu \mathrm{g} / \mathrm{ml})\end{array}$ \\
\hline Control & $22.05 \pm 2.51$ & $1.91 \pm 0.02$ & $458.7 \pm 12.7$ & $2.67 \pm 0.12$ & 0.0058 & $31.07 \pm 0.80$ & $1.43 \pm 0.10$ \\
\hline $4 \mathrm{~d}$ fasting & $\begin{array}{c}21.46 \pm 2.29 \\
(-26.75 \%)\end{array}$ & $\begin{array}{l}1.66 \pm 0.01^{*} \\
(-13.08 \%)\end{array}$ & $\begin{array}{c}639.3 \pm 18.9^{*} \\
(+39.37 \%)\end{array}$ & $\begin{array}{c}3.45 \pm 0.17^{*} \\
(+29.2 \%)\end{array}$ & $\begin{array}{c}0.0053 \\
(-8.62 \%)\end{array}$ & $\begin{array}{c}30.09 \pm 1.39 \\
(-3.15 \%)\end{array}$ & $\begin{array}{c}0.99 \pm 0.11^{*} \\
(-31 \%)\end{array}$ \\
\hline $\begin{array}{l}2 \mathrm{~d} \text { fasting } \\
2 \mathrm{~d} \text { refeeding }\end{array}$ & $\begin{array}{c}21.32 \pm 0.76 \\
(-3.31 \%)\end{array}$ & $\begin{array}{c}1.72 \pm 0.01^{*} \\
(-9.94 \%)\end{array}$ & $\begin{array}{c}442.50 \pm 6.25 \\
(-3.53 \%)\end{array}$ & $\begin{array}{c}3.68 \pm 0.27^{*} \\
(+37.8 \%)\end{array}$ & $\begin{array}{l}0.0083 \\
(43 \%)\end{array}$ & $\begin{array}{c}30.80 \pm 3.54 \\
(-0.86 \%)\end{array}$ & $\begin{array}{c}1.06 \pm 0.03 \\
(-25.8 \%)\end{array}$ \\
\hline
\end{tabular}

Table 3. Effect of fasting and refeeding on the specific activities of (a) alkaline phosphatase (AlkPase) and (b) gamma glutamyl transpeptidase (GGTase) in cortical homogenates (CH) and brush border membrane vesicles (BBMV) from whole cortex (WC), superficial cortex (SC) and juxtamedullary cortex (JMC) [Results (specific activity expressed as $\mu$ moles/mg protein/hr) are expressed as Mean \pm SEM for three different preparations. Each preparations includes kidney of 3-4 animals in each group; "Significantly different from control, $\mathrm{p}<0.05$ by group t-test; Values in parentheses represent percent change from control values]

\begin{tabular}{|c|c|c|c|c|c|c|}
\hline \multirow{2}{*}{ Group } & \multicolumn{2}{|c|}{ WC } & \multicolumn{2}{|c|}{ SC } & \multicolumn{2}{|c|}{ JMC } \\
\hline & $\mathbf{C H}$ & BBMV & $\mathbf{C H}$ & BBMV & $\mathbf{C H}$ & BBMV \\
\hline \multicolumn{7}{|c|}{ a) AlkPase } \\
\hline Control & $28.16 \pm 1.62$ & $154.22 \pm 2.53$ & $18.04 \pm 0.30$ & $119.16 \pm 2.79$ & $16.1 \pm 0.489$ & $104.30 \pm 1.50$ \\
\hline \multirow{2}{*}{$4 \mathrm{~d}$ fasting } & $23.55 \pm 0.61$ & $132.74 \pm 5.18^{*}$ & $15.90 \pm 0.39^{*}$ & $93.56 \pm 1.56^{*}$ & $15.8 \pm 0.801$ & $86.09 \pm 0.821^{*}$ \\
\hline & $(-16.3 \%)$ & $(-13.92 \%)$ & $(-11.86 \%)$ & $(-21.48 \%)$ & $(-1.86 \%)$ & $(-17.46 \%)$ \\
\hline $2 \mathrm{~d}$ fasting & $23.36 \pm 1.29$ & $147.58 \pm 1.56$ & $17.30 \pm 0.08$ & $108.1 \pm 2.27$ & $16.5 \pm 0.36$ & $98.80 \pm 1.24$ \\
\hline $2 \mathrm{~d}$ refeeding & $(-17.04 \%)$ & $(-4.30 \%)$ & $(-4.10 \%)$ & $(-9.28 \%)$ & $(-2.48 \%)$ & $(-5.27 \%)$ \\
\hline \multicolumn{7}{|c|}{ b) GGTase } \\
\hline Control & $34.61 \pm 0.03$ & $193.31 \pm 8.64$ & $25.47 \pm 1.60$ & $112.4 \pm 0.20$ & $37.34 \pm 0.165$ & $156.3 \pm 2.27$ \\
\hline \multirow{2}{*}{$4 \mathrm{~d}$ fasting } & $33.01 \pm 1.89$ & $109.53 \pm 7.70^{*}$ & $23.81 \pm 1.85$ & $94.7 \pm 0.22^{*}$ & $36.9 \pm 2.28$ & $117.80 \pm 2.64^{*}$ \\
\hline & $(-4.62 \%)$ & $(-43.3 \%)$ & $(-6.5 \%)$ & $(-15.74 \%)$ & $(-1.17 \%)$ & $(-24.63 \%)$ \\
\hline $2 \mathrm{~d}$ fasting & $33.03 \pm 0.87$ & $200.70 \pm 14.4$ & $23.3 \pm 3.95$ & $100.2 \pm 0.36$ & $40.06 \pm 2.22$ & $143.6 \pm 2.22$ \\
\hline $2 \mathrm{~d}$ refeeding & $(-4.56 \%)$ & $(+3.8 \%)$ & $(-8.51 \%)$ & $(-10.8 \%)$ & $(+7.28 \%)$ & $(-8.12 \%)$ \\
\hline
\end{tabular}



regions

in the activities of above metabolic enzymes (Table 4). Refeeding of rats was also able to bring down the enzyme activities towards the control values. The results indicate differential effects of fasting and fasting-refeeding on the enzymes of carbohydrate metabolism in SC-H and JMC-H.

\section{Effect of fasting and fasting-re-feeding on transport of ${ }^{32} \mathrm{Pi}$ in BBMV-WC, BBMV-SC and BBMV-JMC}

The results summarized in Table 5 indicate that Na-gradient dependent $\left(\mathrm{Na}_{\mathrm{o}}>\mathrm{Na}_{\mathrm{i}}\right)$ transport of $\mathrm{Pi}$ in the initial uphill phase $(5 \mathrm{~s}$ and $20 \mathrm{~s}$ ) was significantly lowered upon $4 \mathrm{~d}$ fasting. However, the uptake at $120 \mathrm{~min}$ was not altered as also observed earlier (Table 5). The re-feeding of fasted rats resulted in the significant increase of Nagradient dependent transport of Pi but was still lower than the control values. The Na-dependent uptake of $\mathrm{Pi}$ at $120 \mathrm{~min}$ (Table 5) and $\mathrm{Na}$ independent uptake of $\mathrm{Pi}$ at $20 \mathrm{~s}$ or $120 \mathrm{~min}$ in the presence of a $\mathrm{K}$ -gradient $\left(\mathrm{K}_{\mathrm{o}}>\mathrm{K}_{\mathrm{i}}\right)$ were not altered by fasting or re-feeding. The effect of fasting and fasting-re-feeding on the Pi uptake was also determined in BBMV-SC and BBMV-JMC. The results summarized in Table 5 indicate that $\mathrm{Na}$-gradient dependent $\mathrm{Pi}$ uptake in the initial uphill phase ( $5 \mathrm{~s}$ ) was significantly lowered after $4 \mathrm{~d}$ fasting (Table 5). The effect appeared to be greater in BBMV SC than in BBMV-JMC. The recovery of Pi uptake due to re-feeding to fasted rats was also observed to be more in BBMV-SC than in BBMV-JMC. Kinetic analyses also showed similar observations (Table 6).

\section{Discussion}

The kidney is vital organ plays essential role in the maintenance of body fluid volume, its composition and $\mathrm{pH}$ with in physiological range. The kidney is a heterogeneous structure consisting of discreet tissue zones e.g., cortex, the outer and inner medulla with individual "organ" characteristics with respect to structure, metabolism and functions. The intra- and inter- nephron heterogeneity distinguished them further which run through these zones [3,11-14]. The metabolic activity, the oxygen tension and the transport functions vary in different tissue of the kidney. For example, the cortex is the site for oxidative metabolism and gluconeogenesis whereas anaerobic glycolysis is prevalent in the medulla. Most solutes, ions and water are reabsorbed in the kidney by its proximal tubule across its BBM which contains a number of hydrolytic enzymes and transport systems. These tubules function differentially in different cortical regions [11].

The present research was carried out to gain comprehensive knowledge regarding adaptive adjustment in rat kidney in general and proximal tubules in particular to maintain a positive balance of

Table 4. Effect of fasting and refeeding on the specific activities of lactate dehydrogenase (LDH), malate dehydrogenase (MDH), fructose 1,6- bisphosphatase (FBPase), glucose-6phosphatase (G6Pase), glucose-6-phosphate dehydrogenase (G6PDH) and malic enzyme (ME) in a) superficial cortical homogenate [(SCH) and b) juxtamedullary cortical homogenate (JMCH) [Results (specific activity expressed as $\mu$ moles/mg protein/hr) are expressed as Mean \pm SEM for three different preparations. Each preparations includes kidney of 3-4 animals in each group; "Significantly different from control, $\mathrm{p}<0.05$ by group t-test; ${ }^{\dagger}$ Significantly different from $4 \mathrm{~d}$ fasted rats, $\mathrm{p}<0.05$ by group t-test; Values in parentheses represent percent change from control values]

\begin{tabular}{|c|c|c|c|c|c|c|}
\hline Group/Enzymes & LDH & MDH & FBPase & G6Pase & G6PDH & ME \\
\hline \multicolumn{7}{|c|}{ a) $\mathrm{SCH}$} \\
\hline Control & $40.16 \pm 1.03$ & $141.70 \pm 11.30$ & $7.86 \pm 0.31$ & $6.56 \pm 0.51$ & $357.0 \pm 20.0$ & $827.30 \pm 11.70$ \\
\hline $4 \mathrm{~d}$ fasting & $\begin{array}{c}27.88 \pm 1.30^{*} \\
(-30.5 \%)\end{array}$ & $\begin{array}{c}116.60 \pm 5.39^{*} \\
(-18 \%)\end{array}$ & $\begin{array}{c}14.32 \pm 0.75^{*} \\
(+82.2 \%)\end{array}$ & $\begin{array}{c}9.68 \pm 0.20^{*} \\
(+47.6 \%)\end{array}$ & $\begin{array}{c}875.50 \pm 21.40^{*} \\
(+145 \%)\end{array}$ & $\begin{array}{c}956.25 \pm 29.00 \\
(+15.6 \%)\end{array}$ \\
\hline $\begin{array}{l}2 \mathrm{~d} \text { fasting } \\
2 \mathrm{~d} \text { refeeding }\end{array}$ & $\begin{array}{c}38.24 \pm 0.89^{*} \\
(-4.78 \%)\end{array}$ & $\begin{array}{c}134.90 \pm 10.10^{\dagger} \\
(-4.79 \%)\end{array}$ & $\begin{array}{c}8.06 \pm 0.61^{\dagger} \\
(+2.54 \%)\end{array}$ & $\begin{array}{c}5.80 \pm 0.28^{\dagger} \\
(-11.58 \%)\end{array}$ & $\begin{array}{c}323.80 \pm 40.30^{\dagger} \\
(+9.29 \%)\end{array}$ & $\begin{array}{c}829.00 \pm 34.40^{\dagger} \\
(+0.2 \%)\end{array}$ \\
\hline \multicolumn{7}{|c|}{ b) JMCH } \\
\hline Control & $52.80 \pm 2.66$ & $176.10 \pm 1.23$ & $5.82 \pm 0.47$ & $4.16 \pm 0.70$ & $449.60 \pm 19.30$ & $856.00 \pm 10.80$ \\
\hline $4 \mathrm{~d}$ fasting & $\begin{array}{c}30.30 \pm 1.26^{*} \\
(-42.6 \%)\end{array}$ & $\begin{array}{c}88.10 \pm 4.50^{*} \\
(-49.9 \%)\end{array}$ & $\begin{array}{c}6.50 \pm 0.57 \\
(+12 \%)\end{array}$ & $\begin{array}{l}4.96 \pm 0.23 \\
(+19.2 \%)\end{array}$ & $\begin{array}{c}1363.30 \pm 47.50^{*} \\
(+203 \%)\end{array}$ & $\begin{array}{c}1178.75 \pm 12.10^{*} \\
(+38 \%)\end{array}$ \\
\hline $\begin{array}{l}2 \mathrm{~d} \text { fasting } \\
2 \mathrm{~d} \text { refeeding }\end{array}$ & $\begin{array}{c}46.76 \pm 3.66^{\dagger} \\
(-34.2 \%)\end{array}$ & $\begin{array}{c}150.30 \pm 1.50^{\dagger} \\
(-14.6 \%)\end{array}$ & $\begin{array}{l}5.88 \pm 0.25 \\
(+1.03 \%)\end{array}$ & $\begin{array}{c}4.40 \pm 0.26 \\
(+5.76 \%)\end{array}$ & $\begin{array}{c}446.00 \pm 23.40^{\dagger} \\
(-0.8 \%)\end{array}$ & $\begin{array}{c}846.80 \pm 29.70^{\dagger} \\
(-1.07 \%)\end{array}$ \\
\hline
\end{tabular}

Table 5. Effect of fasting and refeeding on Na-gradient dependent uptake of ${ }^{32} \mathrm{Pi}$ in brush border membrane vesicles (BBMV) from whole cortex (WC), superficial cortex (SC) and juxtamedullary cortex (JMC) [Results (specific activity expressed as pmoles/mg protein) are expressed as Mean \pm SEM for three different preparations. Each preparations includes kidney of 3-4 animals in each group; $\Delta \%$ overshoot at $20 \mathrm{sec}$ determined as a percent change in uptake form $120 \mathrm{~min}$; ${ }^{S}$ Significantly different from control, $\mathrm{p}<0.05$ by group t-test; ${ }^{\dagger}$ Significantly different from $4 \mathrm{~d}$ fasted rats, $\mathrm{p}<0.05$ by group t-test; Values in parentheses represent percent change from control values]

\begin{tabular}{|c|c|c|c|c|c|c|c|c|c|c|c|c|}
\hline \multirow{3}{*}{ Group } & \multicolumn{12}{|c|}{$\begin{array}{l}\text { Na- gradient dependant } \\
(\mathrm{Na0}>\mathrm{Nai})\end{array}$} \\
\hline & \multicolumn{4}{|c|}{ BBMV-WC } & \multicolumn{4}{|c|}{ BBMV-SC } & \multicolumn{4}{|c|}{ BBMV-JMC } \\
\hline & $5 \mathrm{~s}$ & $20 \mathrm{~s}$ & $120 \mathrm{~min}$ & $\Delta \%$ & $5 \mathrm{~s}$ & $20 \mathrm{~s}$ & $120 \mathrm{~min}$ & $\Delta \%$ & $5 \mathrm{~s}$ & $20 \mathrm{~s}$ & $120 \mathrm{~min}$ & $\Delta \%$ \\
\hline Control & $410.66 \pm 19.20$ & $729.55 \pm 19.9$ & $249.64 \pm 39.7$ & 129.24 & $647.83 \pm 15.19$ & $1211.09 \pm 39.67$ & $311.77 \pm 10.6$ & 288.4 & $336.36 \pm 17.5$ & $841.29 \pm 27.3$ & $297.59 \pm 4.84$ & 194.4 \\
\hline $4 \mathrm{~d}$ fasting & $\begin{array}{c}249.42 \pm 3.20^{*} \\
(-39.2 \%)\end{array}$ & $\begin{array}{c}348.50 \pm 37.6^{*} \\
(-52.2 \%)\end{array}$ & $\begin{array}{c}238.17 \pm 26.7 \\
\quad(-4.59)\end{array}$ & 46.32 & $\begin{array}{c}395.94 \pm 27.8^{*} \\
(-38.8 \%)\end{array}$ & $\begin{array}{c}758.48 \pm 33.67^{*} \\
(-37.3 \%)\end{array}$ & $\begin{array}{c}291.71 \pm 27.07 \\
(-6.43 \%)\end{array}$ & 160 & $\begin{array}{c}247.50 \pm 16.5^{*} \\
(-26.4 \%)\end{array}$ & $\begin{array}{c}509.50 \pm 12.4^{*} \\
(-39.4 \%)\end{array}$ & $\begin{array}{c}260.2 \pm 14.2 \\
(-12.5 \%)\end{array}$ & 95.8 \\
\hline $\begin{array}{l}2 \mathrm{~d} \text { fasting } \\
2 \mathrm{~d} \text { refeeding }\end{array}$ & $\begin{array}{c}376.00 \pm 2.38^{*} \\
(-8.44 \%)\end{array}$ & $\begin{array}{c}617.92 \pm 14.5^{*} \\
(-15.30 \%)\end{array}$ & $\begin{array}{c}205.79 \pm 26.9 \\
(-17.5 \%)\end{array}$ & 200.26 & $\begin{array}{c}590.63 \pm 21.7^{*} \dagger \\
(-8.82 \%)\end{array}$ & $\begin{array}{c}917.34 \pm 24.2 \dagger \\
(-24.3 \%)\end{array}$ & $\begin{array}{c}307.9 \pm 13.1 \\
(-1.24 \%)\end{array}$ & 197.9 & $\begin{array}{c}312.65 \pm 20.2 \dagger \\
(-7.04 \%)\end{array}$ & $\begin{array}{c}713.66 \pm 29.8 \dagger \\
(-15.17 \%)\end{array}$ & $\begin{array}{c}285.83 \pm 23.8 \\
(-3.95 \%)\end{array}$ & 149.5 \\
\hline
\end{tabular}

Table 6. Effect of fasting and refeeding on kinetic parameters of Na-dependant ${ }^{32} \mathrm{Pi}$ uptake as a function of an external Pi concentration by brush border membrane vesicles (BBMV) from superficial cortex (SC) and juxtamedullary cortex (JMC) $\left[\mathrm{K}_{\mathrm{m}}\right.$ : Michaelis Menton constant; $\mathrm{V}_{\text {max }}$ : maximal velocity of enzyme reaction; ${ }^{\dagger}$ pmoles/mg protein/10sec; Values in parentheses represent percent change from control values]

\begin{tabular}{|c|c|c|c|c|}
\hline \multirow{2}{*}{ Group } & \multicolumn{2}{|c|}{ BBMV-SC } & \multicolumn{2}{|c|}{ BBMV-JMC } \\
\hline & $\mathbf{V}_{\max }^{\dagger}$ & $\mathrm{K}_{\mathrm{m}} \times 10^{-3} \mathrm{M}$ & $\mathbf{V}_{\max }^{\dagger}$ & $\mathrm{K}_{\mathrm{m}} \times 10^{-3} \mathrm{M}$ \\
\hline Control & 7272.72 & 7.14 & 3076.9 & 2.94 \\
\hline $4 \mathrm{~d}$ fasting & $1538.46(-79 \%)$ & $2.38(-66.6 \%)$ & $2105.2(-31.58 \%)$ & $1.61(-45 \%)$ \\
\hline $\begin{array}{c}2 \mathrm{~d} \text { fasting } \\
2 \mathrm{~d} \text { refeeding }\end{array}$ & $\begin{array}{l}4000.0 \\
(-45 \%)\end{array}$ & $\begin{array}{c}3.84 \\
(-46.21 \%)\end{array}$ & $\begin{array}{c}1000.0 \\
(-67.5 \%)\end{array}$ & $\begin{array}{c}2.63 \\
(-10.5 \%)\end{array}$ \\
\hline
\end{tabular}



regions

various metabolites and Pi involved in energy production needed for various renal functions under fasting and after re-feeding conditions. Fasting caused marked reduction in body weights. The kidney and cortex weight were also declined in parallel but re-feeding to fasted rats reversed the effect of fasting in these parameters. However, serum and urine creatinine were not affected by fasting as well as re-feeding suggesting that the body adapts well and normal kidney functions remained intact.

The transport of various ions and solutes in the kidney are largely dependent on the availability of ATP which is provided by various metabolic pathways. Since kidney is heterogeneous structure consisting of several tissue zones which interact internally in different environmental situations e.g., oxygen tension and composition of metabolites exhibiting diverse metabolic activity and thus functional capacity. In view of this the effect of fasting and fasting-re-feeding was studied in the homogenates obtained from different parts of the cortex. As shown in the "Results", fasting significantly decreased the activity of $\mathrm{LDH}$ and MDH in superficial (SC) and juxta-medullary cortex (JMC) as reported earlier [10]. The effect on LDH seems significantly higher in JMC compared to SC as anaerobic glycolysis is more prevalent in the medulla than cortex. In contrast, activity of gluconeogenesis enzymes, FBPase and G6Pase profoundly increased by fasting. Re-feeding to fasted rats increased the activity of $\mathrm{LDH}$ and $\mathrm{MDH}$ whereas decreased the activity of FBPase and G6Pase closed to control unfasted rats. The enzymes of glucose metabolism and glucose synthesis are differentially distributed in the cortex and medulla $[11,15]$. The oxidative metabolism and gluconeogenesis is more prevalent in superficial cortex whereas anaerobic glycolysis is in juxta-medullary region [16]. These results suggest that in the absence of food the glucose degradation was slowed down but glucose production by gluconeogenesis was increased and when the food was available during re-feeding the normal metabolic activities were restored. This shows a great metabolic adaptation by the kidney under acute situations.

Glucose is also oxidized by G6PDH and NADP-malic enzyme (ME) which have important roles in NADPH production that is being utilized by the kidney in drug metabolism, glutathione handling and in the synthesis of lipids for membranes [17]. Fasting markedly increased the activities of both of these enzymes and the resulting increased NADPH might be responsible for higher serum cholesterol and phospholipids. Since cholesterol and phospholipids are essential membrane components they could be utilized in the repair and regeneration of cellular membranes affected by fasting. Increased cellular NADPH could also be utilized to reduce oxidative stress as has been observed in intestine and liver by fasting [18]. In contrast refeeding of fasted rats was also able to bring down the enzyme activities towards the control values as the burden of fasting may have been ameliorated.

The transport of ions and solutes is major work function of kidney. There is a direct link between the metabolic activity and transport functions which are dependent on available metabolites, energy and $\mathrm{BBM}$ integrity. It has been shown that Na-gradient dependent $\mathrm{Pi}$ transport differs in BBMV-SC and BBMV-JMC $[11,19]$. BBM integrity was assessed by determining the activity of its biomarker enzymes. The activity of BBM marker enzymes; AlkPase and GGTase was decreased although differentially in the homogenates and BBMV prepared from different kidney tissues. Re-feeding to fasted rats, however prevented fasting-induced decrease in BBM enzyme activities Kinetic analysis conducted on BBMV prepared from WC, SC and JMC revealed that the decrease/increase in enzyme activities in BBMV-SC and BBMV-
JMC by fasting/re-feeding was due to alterations both in Vmax and $\mathrm{Km}$ values but it was differentially observed In BBMV-SC and BBMV-JMC. It has been well established that AlkPase and GGTase are differentially located and organized in the thickness of BBM and are affected differentially under different patho-physiologic situations $[3,11,20]$. Thus these enzymes appeared to be differentially affected by fasting [10] and or re-feeding due to their location and organization in different membranes. The effect of fasting was also different on intestine and kidney BBM enzymes $[2,8,20]$.

The bulk of filtered $\mathrm{Pi}$, required for the production of metabolites and ATP is transported by renal proximal tubule (located in the cortex and part of medulla) across its BBM by a Na-dependent active transport process $[1,21]$. To assess the functional aspect, the transport of Pi was determined in BBMV prepared from whole, superficial and juxta-medullary cortex. The results show that Na-gradient dependent transport of Pi in initial uphill phase at $5 \mathrm{~s}$ and $20 \mathrm{~s}$ significantly decreased by fasting in both BBMV-SC and BBMV-JMC albeit differentially. The effect of fasting on Pi uptake was not observed at $120 \mathrm{~min}$ (equilibrium phase) and in the absence Na-gradient. However, re-feeding caused reversal of fasting effect and resulted in increased $\mathrm{Pi}$ uptake both in BBMV-SC and BBMV-JMC. The effect of fasting or re-feeding on $\mathrm{Pi}$ uptake was not observed at $120 \mathrm{~min}$ (equilibrium phase) and in the absence Na-gradient. Kinetic analysis revealed that decrease in the Pi transport was due to decrease of both $\mathrm{V}_{\max }$ and $\mathrm{K}_{\mathrm{m}}$ values whereas the increase in Pi transport by re-feeding was due to increase in both $\mathrm{V}_{\text {max }}$ and $\mathrm{K}_{\mathrm{m}}$ values. The decrease in Pi transport by fasting or increase by re-feeding both can be attributed to the decrease or increase in the number of Na-gradient-dependent Pi transporters and in part due to alterations in the intrinsic properties of the transporters as observed in many pathological conditions [14,17]. Recently, oxidative stress and reduction in several growth factors are considered to be involved in fasting-induced deleterious effects $[18,22]$.

In summary the present results demonstrate that fasting decreased the enzymes of glucose degradation/oxidation in parallel to the decrease in BBM enzymes along with decrease in the transport of Pi by BBMV-SC and BBMV-JMC albeit differently. This indicates that fasting lowered the energy production and hence the BBM integrity and Pi transport. In contrast, Re-feeding counteracted the effect of fasting and increased the enzymes of glucose metabolism and BBM enzymes activity i.e., membrane integrity leading to the increase in Pi Transport. This notion is further supported by the fact that serum and urine Pi levels were also degreased fasting limiting its availability for metabolite synthesis and ATP formation. In opposite to that re-feeding increased serum Pi levels to support metabolic activity as well as transport functions. In general fasting is known to increase degradation or decrease synthesis of bio-components whereas re-feeding does the opposite. The role of oxidative stress was also suggested as one of the mechanisms caused by fasting and anti-oxidant mechanism might be strengthen by re-feeding after fasting [18,22].

\section{Acknowledgements}

This work was supported by a research grant (SO/SO/B-93/89) from the Department of Science and Technology (DST) to A. N. K. Y. Financial support to the department from University Grant Commission, New Delhi, India is also gratefully acknowledged.

\section{Competing interest}

The authors declare that they have no competing interests. 


\section{References}

1. Kempson SA, Dousa TP (1986) Current concepts of regulation of phosphate transport in renal proximal tubules. Biochem Pharmacol 35: 721-726. [Crossref]

2. Farooq N, Yusufi ANK, Mahmood R (2004) Effect of fasting on enzymes of carbohydrate metabolism and brush border membrane in rat intestine. Nutr Res 24 407-416.

3. Khundmiri SJ, Asghar M, Khan F, Salim S, Yusufi AN (1997) Effect of reversible and irreversible ischemia on marker enzymes of BBM from renal cortical PT subpopulations. Am J Physiol 273: F849-F856.

4. Perazella MA (2009) Renal vulnerability to drug toxicity. Clin J Am Soc Nephrol 4: 1275-1283. [Crossref]

5. Kempson SA, Shah SV, Werness PG, Berndt T, Lee PH, et al. (1980) Renal brush border membrane adaptation to phosphorus deprivation; effects of fasting compared to low phosphorus diet. Kidney Int 18: 36-47.

6. Garcia-Salguero L, Lupianez JA (2007) Metabolic adaptation of the renal carbohydrate metabolism. I. Effects of starvation on the gluconeogenic and glycolytic fluxes in the proximal and renal distal tubules. Am J Physiol Renal Physiol 293: F325-F332.

7. Gredilla R, Barja G (2005) Minireview: the role of oxidative stress in relation to caloric restriction and longevity. Endocrinology 146: 3713-3717. [Crossref]

8. Farooq N, Priyamvada S, Ariwarasu NA, Saleem S, Khan F, et al. (2006) Influence of Ramadan type fasting on enzymes of carbohydrate metabolism and brush border membrane in small intestine and liver of rat used as a model. Br J Nutr 96: 1087-1094.

9. Salim S, Farooq N, Priyamvada S, Asghar M, Khundmiri SJ, et al. (2007) Influence of Ramadan-type fasting on carbohydrate metabolism, brush border membrane enzymes and phosphate transport in rat kidney used as a model. Brit J Nutr 98: 984-990. [Crossref]

10. Salim S, Farooqui Z, Asghar M, Khundmiri SJ, Khan F, et al. (2017) Effect of fasting on enzymes of carbohydrate metabolism and brush border membrane and on Pi transport in superficial and juxta-medullary cortex of rat kidney. J Nutr Food Sci 7: 588-594.

11. Yusufi ANK, Murayama N, Gapstur SM, Szczepanska-Konkel M, Dousa TP (1994) Differential properties of brush border membrane vesicles from early and late proximal tubules of rat kidney. Biochim Biophys Acta 1191: 117-132
12. Khundmiri SJ, Asghar M, Khan F, Salim S, Yusufi AN (2004) Effect of ischemia and reperfusion on enzymes of carbohydrate metabolism in rat kidney. J Nephrol 17: 377 383. [Crossref]

13. Lowry OH, Rosebrough NJ, Farr AL, Randall RJ (1951) Protein measurement with the Folin phenol reagent. $J$ Biol Chem 193: 265-275. [Crossref]

14. Khundmiri SJ, Asghar M, Banday AA, Khan F, Salim S, et al. (2005) Effect of reperfusion on sodium dependent phosphate transport in renal brush border membranes. Biochimica Biophysica Acta 1716: 19-28.

15. Guder WG, Ross BD (1984) Enzyme distribution along the nephron. Kidney Int 26 101-111. [Crossref]

16. Gerich JE (2010) Role of the kidney in normal glucose homeostasis and in the hyperglycaemia of diabetes mellitus: therapeutic implications. Diabetic Med 27: 136-142.

17. Priyamvada S, Priyadarshini M, Arivarasu NA, Farooq N, Khan S, et al. (2008) Studies on the protective effect of dietary fish oil on gentamicin-induced nephrotoxicity and oxidative damage in rat kidney. Prostaglandins Leukot Essent Fatty Acids 6: 369-81.

18. Sorensen M, Sanz A, Gómez J, Pamplona R, Portero-Otín M, et al. (2006) Effects of fasting on oxidative stress in rat liver mitochondria. Free Radic Res 40: 339-347. [Crossref]

19. Murer H, Biber J (1993) Structural identification of brush border membrane transport systems-towards an understanding of regulatory mechanisms. Clin Invest 71: 852-854. [Crossref]

20. Banday AA, Priyamvada S, Farooq N, Yusufi ANK, Khan F (2008) Effect of uranyl nitrate on enzymes of carbohydrate metabolism and brush border membrane in different kidney tissues. Food Chem Toxicol 46: 2080-2088.

21. Murer H, Biber J (1996) Molecular mechanisms of renal apical Na/phosphate cotransport. Annu Rev Physiol 58: 607-618. [Crossref]

22. Mathew TC, Abdeen SM, Dashti H, Asfar S (2017) Green Tea Induced Cellular Proliferation and Expression of Transforming Growth Factor-b1 in the Jejunal mucosa of Fasting Rats. Med Princ Pract 26(4): 343-350. [Crossref]

Copyright: (C2017 Salim S. This is an open-access article distributed under the terms of the Creative Commons Attribution License, which permits unrestricted use, distribution, and reproduction in any medium, provided the original author and source are credited. 